\title{
AN APPLICATION OF A STOCHASTIC SEMI-CONTINUOUS SIMULATION METHOD FOR FLOOD FREQUENCY ANALYSIS: A CASE STUDY IN SLOVAKIA
}

Peter VALENT ${ }^{1}$, Emmanuel PAQUET ${ }^{2}$

\section{Abstract}

A reliable estimate of extreme flood characteristics has always been an active topic in hydrological research. Over the decades a large number of approaches and their modifications have been proposed and used, with various methods utilizing continuous simulation of catchment runoff, being the subject of the most intensive research in the last decade. In this paper a new and promising stochastic semi-continuous method is used to estimate extreme discharges in two mountainous Slovak catchments of the rivers Váh and Hron, in which snowmelt processes need to be taken into account. The SCHADEX method used, couples a precipitation probabilistic model with a rainfall-runoff model used to both continuously simulate catchment hydrological conditions and to transform generated synthetic rainfall events into corresponding discharges. The stochastic nature of the method means that a wide range of synthetic rainfall events were simulated on various historical catchment conditions, taking into account not only the saturation of soil, but also the amount of snow accumulated in the catchment. The results showed that the SCHADEX extreme discharge estimates with return periods of up to 100 years were comparable to those estimated by statistical approaches. In addition, two reconstructed historical floods with corresponding return periods of 100 and 1000 years were compared to the SCHADEX estimates. The results confirmed the usability of the method for estimating design discharges with a recurrence interval of more than 100 years and its applicability in Slovak conditions.
Address

1 Department of Land and Water Resources Management, Faculty of Civil Engineering, Slovak University of Technology, Slovakia

2 Electricité de France (EDF-DTG), Grenoble, France

* Corresponding author: peter_valent@stuba.sk

\section{Key words}

- SCHADEX

- MEWP,

- MORDOR,

- Stochastic rainfall model,

- Rainfall-runoff model,

- Flood frequency analysis.

\section{INTRODUCTION}

Flood frequency analysis (FFA) and the quantification of a catchment's extreme behaviour has always been a core subject of research interest in hydrology since the early stages of its establishment as a scientific discipline. The magnitude of a design flood is the basis for designing engineering and hydraulic structures, flood mitigation measures, or integrated flood management and risk analysis. It also plays an important role in designing traffic systems near large rivers (such as in: Schlosser et al., 2017), as well as in urban and landscape planning. The design flood is in many cases associated with a return period or a probability, the selection of which depends on the nature and scale of the task for which it is used (Saghafian et al., 2014). An accurate estimation of its main characteristics (magnitude and return 
period) is extremely important, since its underestimation may lead to losses in life and property and its overestimation to inefficient use of investments.

\subsection{Statistical approaches}

Traditionally, statistical analysis methods have been used to estimate design flood characteristics (most often, peak flow) by fitting a probability distribution to either an annual maximum or a peaks-overthreshold series of observed flood peaks (Bezak et al., 2014; Cunnane, 1973; Rao et al., 2000). The probability distribution is usually extrapolated to obtain peak flows associated with a low probability of exceedance or a large return period. This approach assumes that the analysed series is an independent and identically distributed (i.i.d.) random variable, which means that its stationarity is preserved. In many cases this assumption is not valid, since most of the catchments where FFA needs to be carried out have been affected by changes in land use or climate characteristics. Moreover, the selection of an appropriate distribution and the estimation of its parameters is often controversial and subject to many disputes (e.g., Cunnane, 1989; Bobée et al., 1993). However, the greatest limitation of the statistical approach is linked to the quantity and quality of the analysed flood peaks. The quality of the data is very often determined by the uncertainty of the rating curve especially its extrapolated part for high discharges (Di Baldassarre et al., 2009; Lang et al., 2010; Rahman et al., 2014). Since in most cases the FFA is used to estimate peak flows with a very small probability of exceedance (a high return period), large errors and high degrees of uncertainty can occur when a series of insufficient length is used (Klemeš, 1993). One of the ways to increase the length of the analysed series, and thus reduce the uncertainty of extreme quantile estimates, is to use regional FFA methods, by which the data from hydrologically similar catchments are used. This approach could also be used in ungauged catchments (see e.g., Kohnová et al., 2006; Gaál, Kyselý and Szolgay, 2008; Blöschl et al., 2013).

\subsection{Deterministic or design storm approaches}

Another group of methods for estimating design flood characteristics makes use of precipitation records, which are often more available in terms of denser networks of rain gauges and more extensive (longer) records, that are less uncertain and less influenced by manmade activities in the catchments (Bras et al., 1985; Saghafian et al., 2014). The simplest types of methods, which utilize rainfall depth data, are referred to as deterministic or design storm methods. They are based on the selection of a design storm, which is defined by a rainfall depth, duration, return period (all three from an intensity-duration-frequency curve) and shape, and which is transformed into a design flood hydrograph using an event-based rainfall-runoff model (Rogger et al., 2012). The simplicity of these types of methods and their computational efficiency means that they are widely used in many countries and still dominate the methods used in practice (ASCE, 1996; DVWK, 1999; FEH, 1999; Ball et al., 2016). Saghafian et al. (2014) note that even though some of the uncertainties associated with discharge measurements and their length are removed by these methods in favour of less uncertain rainfall depth measurements, rainfall loss and rainfall-runoff models constitute new sources of uncertainties. Moreover, design storm methods rely on the following critical assumptions and choices to be made: the design storm event generates a design flood of the same return period (Adams et al., 1986; Rogger et al., 2012; Viglione et al., 2009); the subjective choice of the design storm hyetograph (Asquith et al., 2003); the subjective estimation of initial catchment conditions prior to the design storm event (Camici et al., 2011); and the need to estimate the initial and continuous losses from the design storm (Gamage et al., 2015; Ball et al., 2016).

\subsection{Derived flood frequency approaches}

The development of methods for estimating design flood characteristics took a new direction when Eagleson published an important paper (1972), in which he introduced the concept of derived flood frequency (DFF) distributions. This concept combines statistical and deterministic methods when taking into account the joint probability nature of flood-producing variables ( $\mathrm{Li}$ et al., 2016). Eagleson's model (1972) combined a stochastic storm generator and a kinematic wave model of runoff propagation to obtain the flood frequency curve. In all of the DFF approaches the statistical methods are represented by stochastic rainfall models (also known as weather generators) and the deterministic methods by rainfall-runoff models of various complexities. Existing DFF methods could broadly be categorized into event-based (Lamb, 2005) and continuous simulation (Boughton et al., 2003) approaches. Methods combining the advantages of both approaches have also been proposed (see e.g., Paquet et al., 2013; Li et al., 2014; Flores-Montoya et al., 2016).

Event-based approaches (some authors such as Li et al. (2016) or Boughton and Droop (2003) also include design storm approaches in this category) usually require fitting a unique statistical distribution to input variables (rainfall intensity, rainfall duration, antecedent soil moisture conditions). They are further used to derive a flood frequency distribution by solving the integral of their joint probability function, which is done either analytically or numerically (Eagleson, 1972) by methods such as Monte Carlo simulations (Rahman et al., 2002). One of the benefits of this approach, apart from its high computational efficiency, is the fact that no assumptions about the initial catchment conditions or extreme rainfall have to be made. On the other hand, the disadvantages include problems with the estimation of the distributions of the input variables and the method used to derive the flood frequency distribution (analytical approaches have been proved to result in poor performances (Loukas et al., 1996)).

Continuous simulation approaches use stochastic rainfall models to generate long synthetic time series of rainfall depths, which are subsequently transformed into time series of flows of the same length using a continuous rainfall-runoff model. The resulting time series of flows can be used to extract various flood characteristics such as flood peaks, volumes or durations. Their extreme quantiles could be estimated using traditional statistical approaches, without the need to extrapolate the flood frequency curve. Moreover, the joint probabilities of the flood characteristics could also be estimated by multivariate flood frequency analysis (see e.g.: Gaál et al., 2016; Grimaldi and Serinaldi, 2006; Kohnová et al., 2016; Papaioannou et al., 2016; Szolgay et al., 2015, 2016a, 2016b). The advantage of using stochastic rainfall models lies in their ability to generate various hydrological situations with very low probabilities of occurrence (such as combinations of intensive precipitation and rapid snow melt or intensive precipitation on a saturated catchment), which are not present in the historical records used. In addition, the synthetic time series of input variables are by nature homogenous and stationary, without the impact of any natural or manmade processes. When compared to the very popular design storm approaches, no assumptions about the initial state of the catchment, the rainfall loss model, or the duration and shape of the hyetograph need to be taken into account (Boughton et al., 2003). A clear disadvantage of this approach is its high computational requirements, especially when, e.g., very long time series are generated (Boughton and Hill (1997) generated 1 million years of daily streamflow data), a complex rainfall-runoff model is used (most authors use lumped (Va- 
lent et al., 2015) or semi-distributed models (Cameron et al., 1999)), high temporal resolution is required, or an uncertainty analysis is performed. Blazkova and Beven (2004) underlined the fact that while hydrologically consistent, the continuous simulation approach depends on assumptions about a number of different model components. The results will therefore only be as valid as these models are adequate. This is especially true in the case of rainfall inputs, which play a key role in the reliability of this approach (Blazkova et al., 2004), the high temporal and spatial variability of which are a challenge to model (Ailliot et al., 2015; Sun et al., 2016). This problem is even more evident when multi-site rainfall models are used or when rainfall inputs with a high temporal resolution are generated.

Despite the fact that multiple studies have shown the superiority of the continuous simulation approach over the statistical and design storm approaches (see, e.g., Boughton and Hill, 1997; Newton and Walton, 2000), there has been an effort to develop methods which would overcome the limitations of event-based models (of both catchment runoff and rainfall) by coupling them with some of the techniques used in continuous simulation approaches. These methods are referred to as semi-continuous. Li et al. (2014) introduced a socalled hybrid-causative event (HCE) approach, in which the extreme rainfall distribution is estimated from a long continuous simulation run of rainfall, and the antecedent catchment state conditions are estimated using a short (e.g., 30-50 years) continuous simulation of catchment runoff, which provide inputs to event-based rainfall-runoff modelling. When compared to continuous simulation approach, this method produced similar results with a much higher computational efficiency (a factor of 100-1000) and significantly reduced the biases in the estimation of design discharges, when compared to design storm approaches. Another semi-continuous method has been proposed by Flores-Montoya et al. (2016). It uses a spatial-temporal stochastic rainfall model (RainSim) to generate continuous series of rainfall inputs and a distributed event-based rainfall-runoff model (RIBS) to create complete hydrographs. In order to overcome the problem of selecting the initial state of the catchment, a new probabilistic calibration-simulation approach has been proposed. The SCHADEX method (Paquet et al., 2013) represents a very unique concept that superimposes synthetic rainfall events on historical records and transforms them into corresponding hydrographs using a conceptual event-based rainfall-runoff model. The method is subject to rapid development and is even becoming popular outside the borders of the country, i.e. France, in which it was developed. In Slovakia, Hlavčová et al. (2005) proposed a method which utilizes a continuous simulation of catchment runoff to simulate pre-flood soil moisture conditions. The method randomly selects historical pre-flood soil moisture conditions and combines them with synthetic extreme precipitation scenario ( 1 to 5 day precipitations were estimated using a statistical distribution, and further disaggregated into days using a method of fragments). The duration of the synthetic rainfall event was kept equal to the historical one of the selected historical period. The corresponding floods were simulated on an event-base basis.

In this study, the SCHADEX method is used to estimate extreme quantiles of peak flows in the catchments of the Váh and Hron rivers, which are situated in the mountainous part of Slovakia. The results of the SCHADEX application are compared with two reconstructed historical floods and with peak flows with corresponding return periods of 10,20,50 and 100 years, which were estimated by fitting an extreme-value probability distribution to the annual maximum series of peak flows. The main purpose of this study is to evaluate the ability of this method to estimate extreme peak flows with very low probabilities of occurrence, and to identify its limitations for practical use.

\section{STUDY CATCHMENTS}

The SCHADEX method, which utilizes a semi-continuous simulation of catchment runoff, was applied to two Slovak mountainous catchments: a) the Váh at Liptovský Mikuláš and b) the Hron at Banská Bystrica. The position of Slovakia in Central Europe determines the predominant continental type of climate in both catchments. The particular catchments were selected due to the availability of both daily and hourly discharge values and their similarity in terms of size, morphology, geology, climate, land cover, and flow regimes. They are both situated in the northern part of Slovakia in the mountainous region and share a common border at a ridge of the Low Tatras mountain range (see Fig. 1). The basic characteristics of the selected catchments are summarised in Table 1.

The River Váh catchment is located in the northern part of Slova-
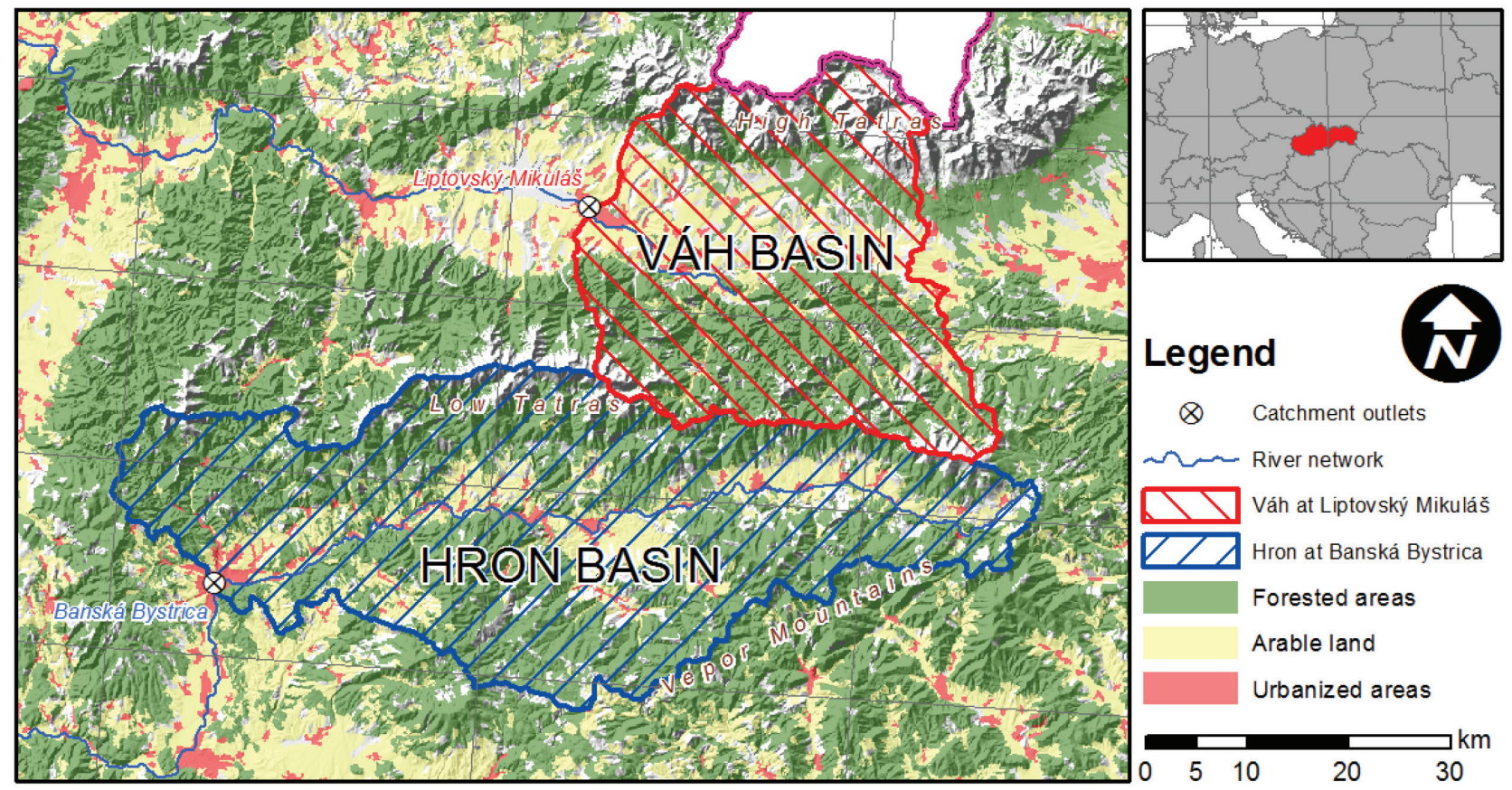

$\otimes \quad$ Catchment outlets

$\sim \sim$ River network

$\checkmark$ Váh at Liptovský Mikuláš

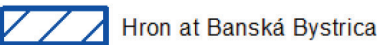

Forested areas

Arable land

Urbanized areas

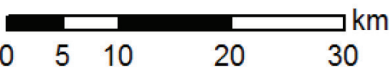

Fig. 1. Location of the selected catchments within Slovakia. The left picture also shows three types of land cover. 
kia and drains an area of $1100.6 \mathrm{~km}^{2}$. It lies between the two highest Slovak mountains, i.e., the High Tatras in the north and the Low Tatras in the south. The mean altitude of the catchment is $1090 \mathrm{mASL}$, and its highest point is Kriván (2494 mASL). The regime of the catchment runoff has a strong seasonal effect, with the highest flows in May and the lowest in the winter months (Fig. 2). Most of the floods occur in May (more than 33\%) and are induced by the rapid melting of snow cover combined with steady rain. The mean annual runoff calculated for the period between 1981 and 2010 was $19.3 \mathrm{~m}^{3} / \mathrm{s}$ (553 mm/year) with minimum and maximum values recorded in this period of 4.2 and $259.9 \mathrm{~m}^{3} / \mathrm{s}$ respectively (recorded on 10.3.1996 and 9.7.1997). The daily flow data, which were available for the analysis, spanned a period between 1981 and 2010. In addition, hourly flow data from the period between 1.11.1988 and 31.10.2002 were also used. The daily precipitation data came from 28 rain gauge stations situated within the catchment and in its near vicinity. The data were used to create a time series of areal precipitation for a period between 1981 and 2010 using an inverse distance weighting method (IDW). The mean annual precipitation amount for this period was $832 \mathrm{~mm} /$ year with July being the wettest month $(106.8 \mathrm{~mm})$ and February the driest one $(42.9 \mathrm{~mm})$. The daily air temperature data came from 6 climatic stations, and also spanned a period between 1981 and 2010. They were used to estimate mean daily air temperatures at the catchment mean elevation. The mean annual air temperature estimated for the given period was $9.8^{\circ} \mathrm{C}$, with $19.8^{\circ} \mathrm{C}$ and $-0.9^{\circ} \mathrm{C}$ for the summer (JJA) and winter (DJF) seasons, respectively.

The second catchment, i.e., the River Hron, lies southwards of the River Váh catchment. It is relatively narrow with an east-west orientation. The northern part of the catchment is formed by the Low Tatras mountain range, with its highest peak of Dumbier (2042 mASL), while its southern part is formed by the much smaller Vepor Mountains. The catchment drains an area of $1768.2 \mathrm{~km}^{2}$, and has a mean altitude of $845 \mathrm{mASL}$. The elevation of its outlet is at $334 \mathrm{mASL}$. The runoff regime of the catchment is very similar to that of the River Váh catchment, with the highest flows occurring during the seasonal snowmelt period in April (see Fig. 2) and more than $40 \%$ of its floods in April and May. The mean annual runoff for the period 1981-2010 is $23.1 \mathrm{~m}^{3} / \mathrm{s}(471 \mathrm{~mm} /$ year), with minimum and maximum values of 4.9 and $236.7 \mathrm{~m}^{3} / \mathrm{s}$, respectively (recorded on 25.12 .2003 and 12.3.1981). Similarly to the first catchment, all the input datasets were collected for the same period, including the hourly flow data from a period between 1.11.1988 and 31.10.2002. The available precipitation data came from 24 rain gauges and were processed into areal precipitations using the same method as in the case of the River Váh catch-

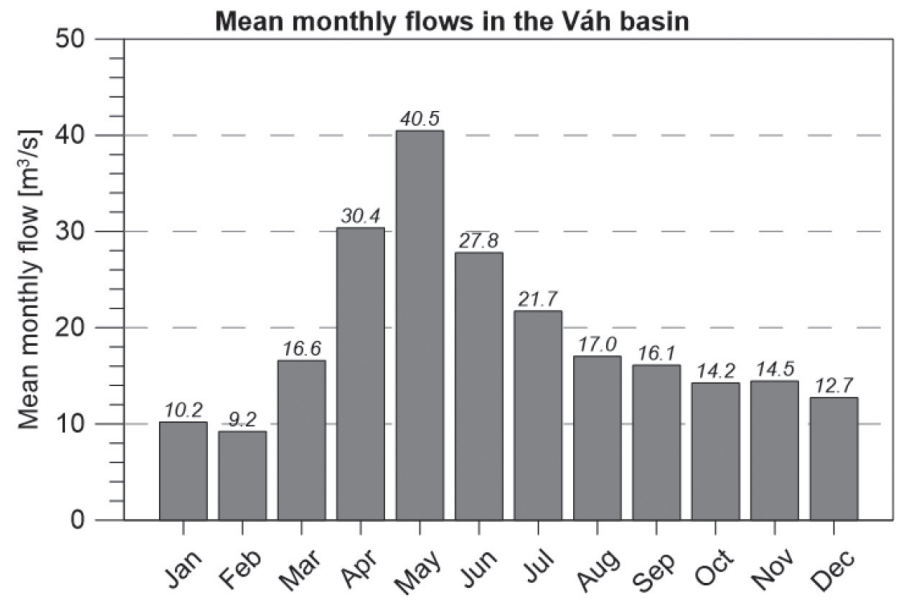

Tab. 1. Basic characteristics of the Váh and Hron catchments.

Characteristics Váh at LM Hron at BB

Physiography

Catchment area $\left(\mathrm{km}^{2}\right)$

1100.6

1768.2

Mean elevation ( $m A S L$ )

1090.3

Min elevation ( $m A S L)$

567.7

Max elevation (mASL)

2494

Climate

Mean annual precipitation

(mm/year)

Highest mean monthly

precipitation ( $\mathrm{mm}$ )

106.8

101.8 (Jun)

Lowest mean monthly

precipitation $(\mathrm{mm})$

46.6 (Feb)

Mean annual air temperature $\left({ }^{\circ} \mathrm{C}\right)$

Mean summer air temperature

(JJA) $\left({ }^{\circ} \mathrm{C}\right)$

Mean winter air temperature

(DJF) $\left({ }^{\circ} \mathrm{C}\right)$

Land cover

Arable land (\%)

16.2

Forests (conif./decid./mixed) (\%)

Natural grasslands and pastures (\%) $(46.8,0.0,1.0)(28.9,8.8,25.1)$

Dwarf pine (\%)

Others (e.g., shrubs, lakes, urban areas) (\%)

Hydrology

Mean annual runoff (mm/year)

Month of maximum/minimum flow

$\mathrm{May} / \mathrm{Feb}$ Apr/Sep

ment. During this period as much as $101.8 \mathrm{~mm}$ of the $847 \mathrm{~mm}$ mean annual precipitation amount was recorded in June and only $46.6 \mathrm{~mm}$ in February. The mean annual air temperature estimated from 8 cli-

Fig. 2 Mean monthly flows calculated for the time period between 1.1.1981 and 31.12.2010 for the Váh (left image) and Hron (right image)

catchments.

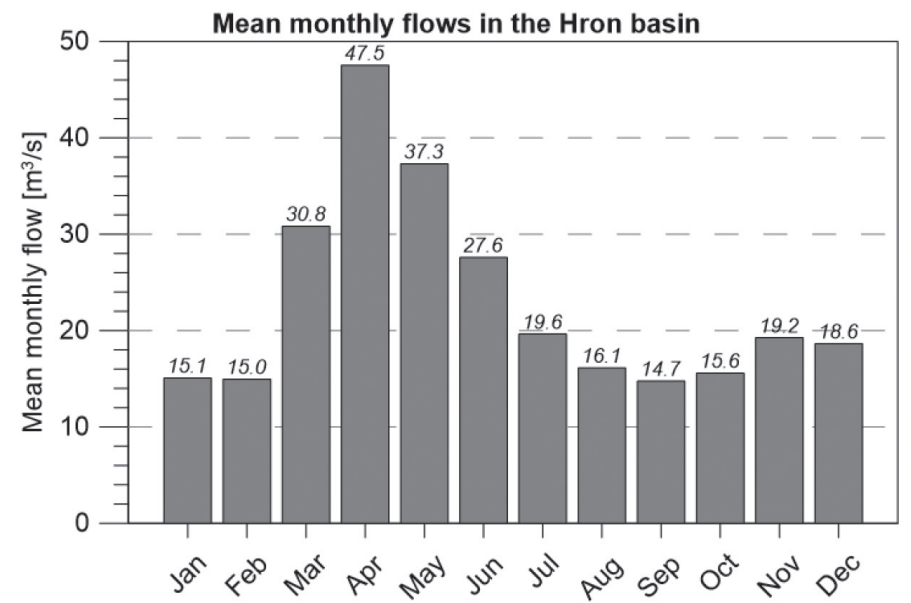


matic stations for the mean elevation was only $5.4^{\circ} \mathrm{C}$, with mean summer and winter temperatures of $14.5^{\circ} \mathrm{C}$ and $-3.9^{\circ} \mathrm{C}$, respectively.

In the case of both catchments most of their area is covered by forest. While the forests of the Hron catchment are composed of coniferous, deciduous and mixed forests, those of the Váh catchment are almost entirely comprised of coniferous trees. In terms of the percentages of agricultural land, the two catchments are identical (see Table 1).

\section{METHODOLOGY}

The SCHADEX is a probabilistic method for flood frequency analysis, which has been developed for a dam spillway design at Electricité de France (EDF), where it has currently been in operational use since 2006. The method is suitable for catchments up to $10^{4} \mathrm{~km}^{2}$ and was originally adapted for mountainous areas (Paquet et al., 2013). Apart from France, it has already been applied and tested in many countries, including Austria (Brigode et al., 2014), Canada (Brigode et al., 2011; Brigode et al., 2015), Slovakia (Valent et al., 2015), and Norway (Lawrence et al., 2014; Paquet et al., 2013), where it is currently being evaluated to become one of the standard methods for estimating extreme floods.

The SCHADEX method couples a special type of stochastic rainfall model with the MORDOR conceptual hydrological model It utilizes a unique concept of semi-continuous simulation, where the hydrological model works in both continuous and event-based simulation modes. The continuous simulation of flows is used to model the state of the catchment (e.g., soil moisture, deep water storage, snow pack), which is used in the event-based modelling of flood events as an estimate of initial conditions. By analysing 84 independent flood events over the period of 1969-2010 in a mountainous French catchment of the River Tarn, Paquet et al. (2013) showed that the coefficient of determination between the daily flood discharges at day $d$ and precipitation amounts aggregated for the time steps $d, d-1$ and $d-2$ is 0.66 ( $d$ is the day of the flood peak). Moreover, the authors found that no significant correlation could be found by including precipitation occurring more than 2 days prior to a flood peak discharge. This implies that as long as the main factor responsible for the generation of large floods is intensive rainfall, there is a strong statistical link between the maximum daily discharge and a three-day rainfall event preceding this discharge. The SCHADEX utilizes these findings when the climatological record is examined to identify all three-day rainfall events producing an over-threshold discharge. Based on the results described in (Paquet et al., 2013), the three-day rainfall events are composed of a central rainfall, which is preceded and followed by smaller rainfalls. The observed centred three-day rainfall events are replaced with synthetic values. The value for the central rainfall is randomly drawn from values between $1 \mathrm{~mm}$ and an extreme value using a Multi-Exponential Weather Pattern (MEWP) distribution introduced by Garavaglia et al. (2010). The rainfall adjacent to the central rainfall was estimated using a ratio relative to the central value. The ratio was randomly drawn from a statistical distribution constructed for: a) both the preceding and following rainfall and b) 4 classes of central rainfall values. The synthetic three-day rainfall events are then used to replace those identified in the climatological record. The runoff induced by this event is computed with the hydrological model, which is fed with the actual climatological record up to the modified rainfall event. Since air temperatures are not generated, observed values are used. This process is repeated hundreds of times for each centred rainfall event in the climatological record. This enables the simulation of several million flood events that could occur in real conditions. It is important to note that the simulation is made at the study time step and leads to the construction of the cumulative

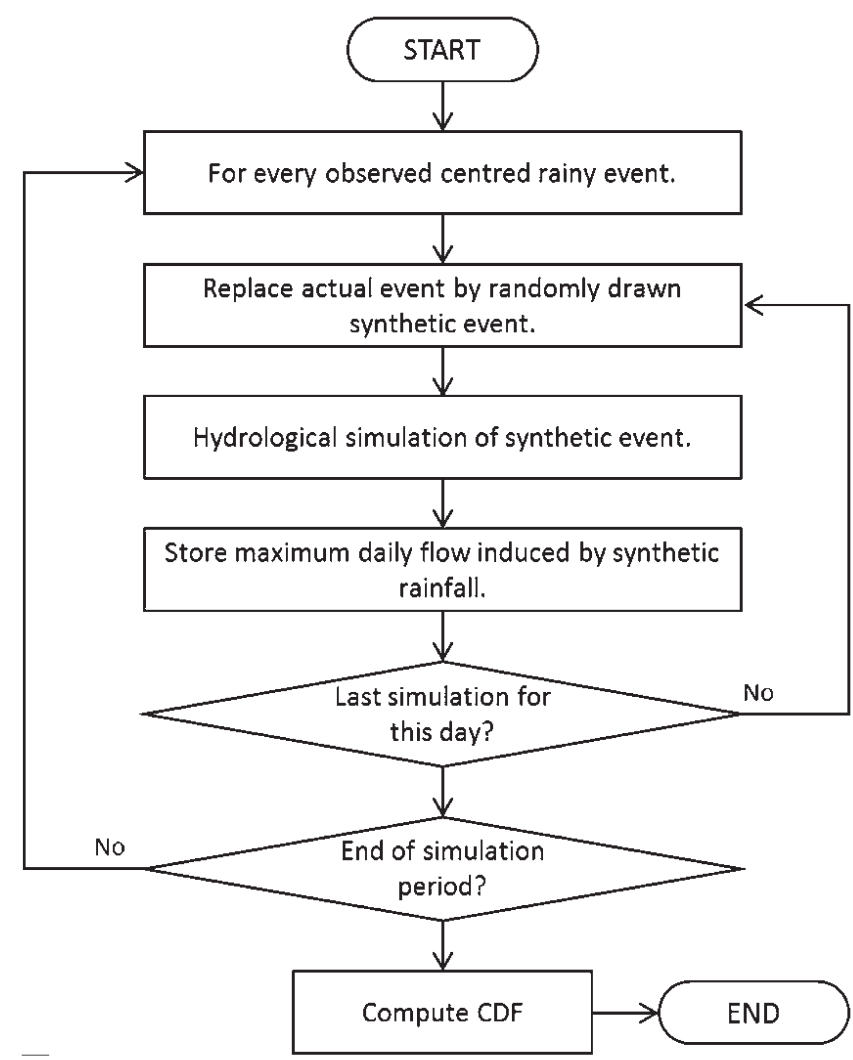

Fig. 3 SCHADEX simulation process (Paquet et al., 2013).

distribution function (CDF) of the simulated maximum discharges at this time step. The selection of the time step depends on multiple factors, among them the catchment's flood dynamic, but with availability of data in many cases being the decisive one. The SCHADEX method adopted a simple approach to transform a CDF of maximum discharges in a simulation time step into a CDF of peak discharges. The approach is based on an analysis of observed flood events for which hydrographs at fine (e.g. hourly) resolution are available. The analysis results in a calculation of a so-called peak-to-volume ratio, which is used to multiply the CDF of the maximum discharges in a simulation time step to get the CDF of peak discharges. The various steps of the SCHADEX simulation are summarised and depicted in Fig. 3. A thorough description of the SCHADEX approach can be found in Paquet et al. (2013).

\subsection{Hydrological modelling}

The SCHADEX method uses the MORDOR rainfall-runoff model to perform both a continuous simulation of catchment runoff used to estimate the catchment saturation conditions as well as to transform generated artificial three-day rainfall events into corresponding maximum flows. MORDOR is a conceptual lumped model developed in the early 1990s at EDF (Garçon, 1996), where it is used in operational hydrology in tasks as diverse as water resources forecasting, hydrological analysis, flood forecasting, low-flow forecasting, flood frequency estimation, and design of water regulation structures (see e.g., Mathevet et al., 2009; Bourqui et al., 2011; Zalachori et al., 2012; Paquet and Lawrence, 2013; Nicolle et al., 2014). The model represents the different components of the hydrological cycle through four reservoirs: superficial storage (contributes to actual evapotranspiration and direct runoff, and simulates soil moisture), evaporation 
storage (contributes to actual evapotranspiration), intermediate storage (distributes water to direct runoff, indirect runoff and percolation into deep storage), and deep storage (determines baseflow). The three runoff components (direct, indirect and base) are routed to the total runoff using a unit hydrograph method. A simple conceptual scheme of the model is displayed in Fig. 4. A thorough description of the MORDOR hydrological model is given in Garçon $(1996 ; 1999)$ and its use within the SCHADEX method in Brigode et al. (2015), Garavaglia et al. (2014; 2017).

The version of the model used in this study has 22 free parameters, from which 11 are dedicated to the simulation of snow accumulation/ melting processes. The model enables the simulation of catchment runoff in time steps ranging from one hour to one day, with model inputs comprised of the mean areal precipitation, air temperature, and catchment runoff used to calibrate the model. In this study, an automatic calibration procedure based on a genetic algorithm was selected to calibrate the model parameters. The calibration procedure was developed at EDF and proved to be as efficient as other commonly used algorithms such as SCE-UA (Duan et al., 1992). The model was calibrated using a multi-criteria compound objective function combining three different criteria for evaluating the model's performance in simulating: a) mean daily flows, b) inter-annual flow regimes, and c) extreme flows induced by the identified centred rainfall events. The individual criteria were aggregated into a single objective function by assigning weights to its components. The function is expressed as follows:

$$
f=\left(1-K G E\left(Q_{\text {day }}\right)\right)+\left(1-K G E\left(Q_{\text {reg }}\right)\right)+\left(1-K G E\left(Q_{\text {max }}\right)\right.
$$

where $K G E\left(Q_{d a v}\right), K G E\left(Q_{\text {reg }}\right)$, and $K G E\left(Q_{\text {max }}\right)$ are Kling-Gupta Efficiency (KGE) measures (Gupta et al., 2009) computed on time-ordered discharges $\left(Q_{d a y}\right)$, inter-annual flow regime $\left(Q_{\text {reg }}\right)$, and maximum flows induced by centred rainfall events $\left(Q_{\text {max }}\right)$. The main purpose of introducing additional objective criteria into the objective function is to maintain a good simulation of maximum flows, while preserving the good day-to-day performance of the model. The KGE, which overcomes some of the problems associated with the traditionally used Nash-Sutcliffe efficiency criterion (Nash et al., 1970), is thoroughly described in Gupta et al. (2009), and is given by the following formula:

$$
\begin{aligned}
K G E & =1-\sqrt{(r-1)^{2}+(\beta-1)^{2}+(\gamma-1)^{2}}, \\
r & =\frac{\operatorname{cov}\left(X_{\text {sim }}, X_{o b s}\right)}{\sigma\left(X_{\text {sim }}\right) \sigma\left(X_{o b s}\right)}, \\
\beta & =\frac{\mu\left(X_{\text {sim }}\right)}{\mu\left(X_{\text {obs }}\right)}, \\
\gamma & =\frac{\sigma\left(X_{\text {sim }}\right) / \mu\left(X_{\text {sim }}\right)}{\sigma\left(X_{\text {obs }}\right) / \mu\left(X_{\text {obs }}\right)} .
\end{aligned}
$$

where $X_{o b s}$ and $X_{\text {sim }}$ are the observed and simulated variables on which the $\mathrm{KGE}$ is calculated, $\operatorname{cov}\left(X_{\text {sim }}, X_{o b s}\right)$ is the covariance between these two variables, $\mu$ is their mean value, and $\sigma$ is the standard deviation. $\mathrm{KGE}$ is subject to maximization, with an ideal value equal to 1 .

Due to the fact that the model was calibrated on the whole time period observed, the process of its verification was based only on using a different criteria to assess its performance in simulating the three components of the compound objective function. The criterion used for the verification was a Nash-Sutcliffe efficiency criterion calculated as:

$$
N S E=1-\frac{\sum_{i=1}^{n}\left(X_{s i m, i}-X_{o b s, i}\right)^{2}}{\sum_{i=1}^{n}\left(X_{o b s, i}-\bar{X}_{o b s}\right)^{2}}
$$

where $n$ is the length of the series used; $X_{o b s, i}$ and $X_{o b s, i}$ are the values of the observed and simulated variables on which the NSE is calculated; and $\bar{X}_{o b s}$ is its average over the whole time period.

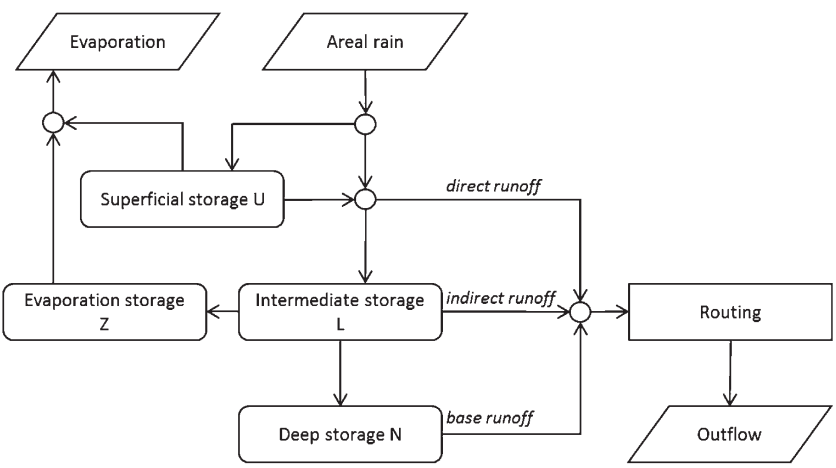

Fig. 4 Conceptual scheme of the MORDOR rainfall-runoff model (Paquet et al., 2013).

\subsection{Probabilistic model of rainfall events}

As described above, the SCHADEX method identifies all three-day centred rainfall events in the climatological record which are above a certain threshold and replaces them with synthetic ones (see Fig. 3). A three-day centred rainfall event is composed of a central and two adjacent rainfalls, both of which are smaller than the central one (see Fig. 5). The central rainfall is generated using the Multi-Exponential Weather Pattern (MEWP) probabilistic model developed at EDF by Garavaglia et al. (2010) and thoroughly tested on datasets from France in Garavaglia et al. (2011), and from Norway in Blanchet et al. (2015). The model is based on both seasonal and weather pattern (WP) subsampling of rainfall series. Prior to the fitting of the MEWP probabilistic model, a WP classification has to be established on a regional scale. The classification is built using a dataset comprised of precipitation and atmospheric pressure data (geopotential heights at $1000 \mathrm{hPa}$ and $700 \mathrm{hPa}$ ) from a sufficiently wide region, but having common synoptic drivers (typically, several hundreds of thousand square kilometres).

Both of the catchments selected are situated close to the Slovak-Polish border. Due to problems with insufficient data from the Polish side of the boundary, the WP classification for this region has still not been finished. As a replacement, a WP classification from neighbouring Austria was used (Brigode et al., 2011). The classification distinguishes between 5 typical weather patterns, which were allocated to each day of the historical records. The seasonal classification was based on the similarity of the rainfall risk in the individual months within each seasons. In both catchments four seasons were identified and are shown in Table 2.

Subsequently, an exponential distribution is used to model each of the considered subsamples above a given quantile, typically 0.7 (one subsample for every combination of a season and WP). At the end, the global MEWP distribution is defined by combining all the individual exponential distributions (for further information on combining the distributions, see Garavaglia et al., 2010, or Brigode et al., 2014) using the relative probability of each WP within the season.

The MEWP probabilistic model is the main model used to generate 2 million synthetic centred rainfall events for each catchment. The two adjacent rainfalls preceding and following the central rainfall, calculated as ratios to the central rainfall, are also generated. Their probabilities are estimated based on an analysis of the adjacent rainfalls observed in the three-day rainfall events identified. More on the estimation of adjacent rainfalls, as well as the accounting for antecedent rainfall to the centred three-day events, is given in Paquet et al. (2013). 


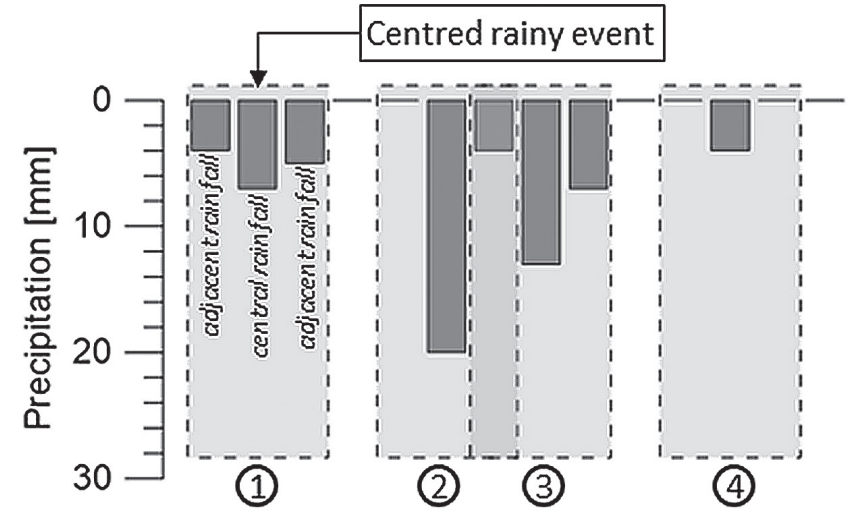

Fig. 5 An example of identifying three-day centred rainy events comprised of the largest central rainfall and two (1,3), one (4) or no (2) adjacent rainfalls. Two centred rainy events can share one common adjacent rainfall (2 and 3 ).

Tab. 2 Seasonal classification used in the MEWP distribution.

\begin{tabular}{ccc}
\hline Season & Váh & Hron \\
\hline 1 & Dec - Mar & Jan - Mar \\
2 & Apr - Jun & Apr - Jun \\
3 & Jul, Aug & Jul, Aug, Oct \\
4 & Sep - Nov & Sep, Nov, Dec \\
\hline
\end{tabular}

\section{RESULTS}

Prior to the first steps of the SCHADEX simulations, the data was subject to a thorough screening and pre-processing in an effort to maintain their stationarity, homogeneity, and correct water balance. The water balance analysis was undertaken in an annual time step, with the mean annual evapotranspiration estimated using the methods of Turc (1954) and Coutagne (1954). In the case of the Váh catchment the analysis indicated that the values of the mean areal precipitation were underestimated by as much as $25 \%$. This could be explained by the fact that more than $22 \%$ of the catchment lies above the rain gauge with the highest elevation. In order to account for this discrepancy, the time series of mean areal precipitation was adjusted to maintain an equilibrium water balance. The analysis also revealed that no further adjustments had to be done in the case of the Hron catchment.

In the next step the hourly discharge data were used to estimate the peak-to-volume ratio, which is used to transform daily discharges of flood events into their corresponding peak values. The estimates of the peak-to-volume ratios were based on an analysis of flood hydrographs selected from the 1.11.1988-31.10.2002 time period. The analysis was conducted on a set of 18 (Váh) and 19 (Hron) hydrographs, which are displayed in Fig. 6. For each hydrograph the value of the non-centred peak-to-volume ratio was calculated as $Q_{1 h} / Q_{24 h}$, where $Q_{24 h}$ is a maximum daily discharge, which includes $Q_{l h}$. The estimated mean value of the non-centred peak-to-volume ratio was 1.31 for both catchments.

\subsection{Calibration of the rainfall-runoff model}

In the process of the model's calibration, the first hydrological year (1.11.1981-31.10.1982) was used as a warm-up period and thus was not included in the calculation of the objective function. In order to assess the quality of the simulations, individual values of the Nash-Sutcliffe efficiency (NSE) measures were calculated for each component of the compound objective function (time-ordered flows, inter-annual flow regime, extreme flows induced by the centred rainfall events). The values of the NSE calculated for the time-ordered flows were 0.77 and 0.82 for the Váh and Hron catchments respectively, indicating a good fit between the observed and simulated flows. The model's performance in preserving the inter-annual flow regime was outstanding, with the NSE values calculated for the mean flows on the individual days within a year as high as 0.97 in both catchments. In addition, a visual assessment of the hydrographs of the inter-annual flow regime confirms that all the seasons were modelled correctly (see Fig. 7). The last component of the optimization function assesses the ability of the model to correctly simulate extreme
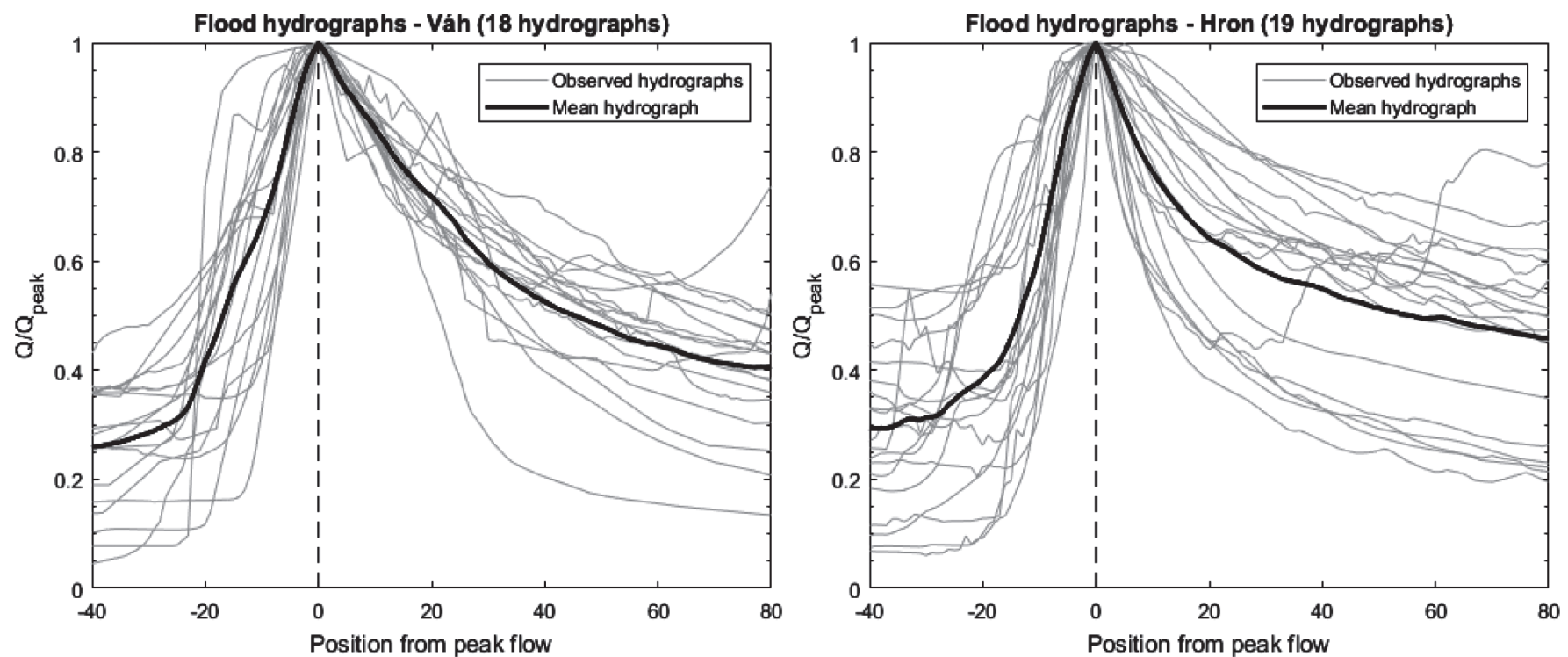

Fig. 6. Selected hydrographs used to calculate the peak-to-volume ratio. The individual hydrographs were scaled to fit a range between 0 and 1. The thick lines show the mean hydrographs calculated from the 18 (Váh-left image) and 19 (Hron-right image) most extreme hydrographs in the period between 1.11.1988-31.10.2002. 

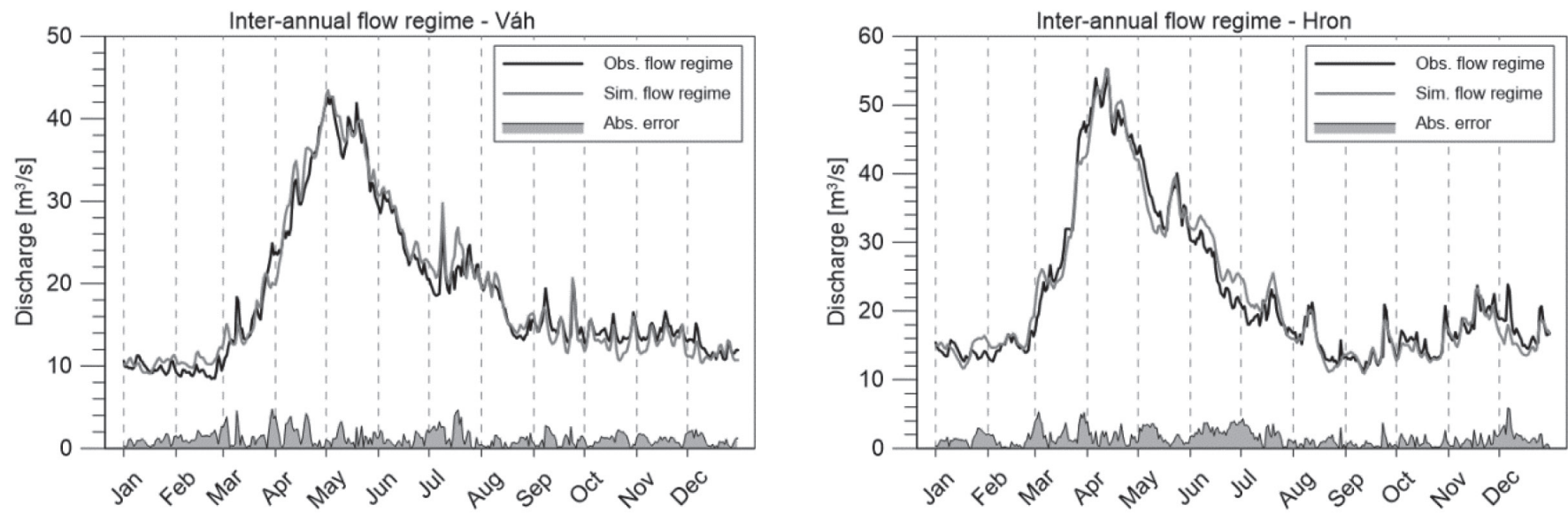

Fig. 7 Comparison of the observed and simulated inter-annual flow regimes in the Váh (left image) and Hron (right image) catchments.
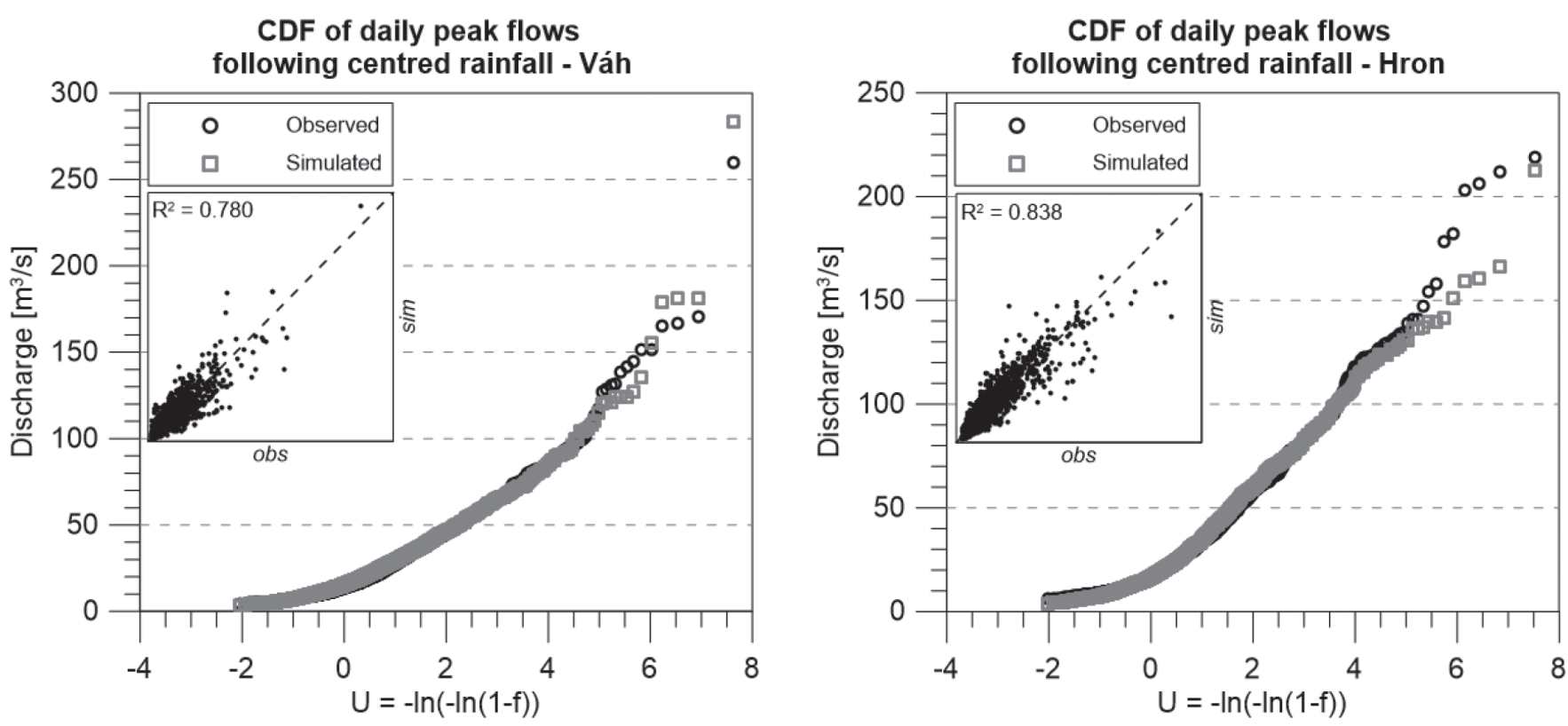

Fig. 8 Comparison of CDFs calculated for the peak flows induced by the observed centred rainfalls. The Q-Q plots inset display the relationship between the observed and simulated peak flows.

flows. The values of the NSE calculated for the peak flows induced by the observed centred rainy events were 0.77 and 0.85 for the Váh and Hron catchments respectively. Fig. 8 shows that despite a very good model performance in the simulation of extreme flows, the model either slightly overestimates (Váh) or underestimates (Hron) some of the most extreme flows. A closer look at the Q-Q plots (insets in Fig. 8 ) of the observed and simulated peak flows shows that the values oscillate around the $f(x)=x$ line, meaning that there is a scatter but no statistical bias between observed and modelled high flows.

\subsection{Building a probabilistic model of centred rainy events}

The probabilistic rainfall model was used to generate synthetic three-day rainfall events with the highest value in the central rainfall. The process of generating these events is comprised of three separate models: (1) a model of the central rainfall, (2) a model of the rainfall preceding the central rainfall, (3) a model of the rainfall following the central rainfall, and (4) a model of the impact of the antecedent rainfall on the central rainfall.
As described in section 3.2, the MEWP probabilistic model was used to generate the values of the central rainfall. The resulting global MEWP model of the central rainfall is shown in the form of CDFs in Fig. 9. It clearly demonstrates that the model fits the observed central rainfall very well, with no significant bias for the highest observed quantiles.

The models of the two antecedent rainfalls were based on a very simple principle, i.e., their values were calculated as a ratio of the central rainfall estimated on a given day. The model selects the value of the ratio $R_{a}$ based on the relative probability of its occurrence in the three-day rainfall events observed. In order to account for any asymptotic properties of the precipitation, the relative probabilities were estimated for four different classes of the central rainfall. The intervals of the classes were set to promote a good simulation of the highest rainfall events, when the number of the events in class $i$ was doubled in class $(i-1)$. The relative probabilities of both adjacent rainfalls calculated for the Váh catchment are given in Table 3. The results suggests that in the case of as much as $40-50 \%$ of the observed rainfall events, the rainfall preceding the central one $\left(P_{a-}\right)$ accounts only for $10 \%$ of the central rainfall. Similarly, the same applies to the rainfall following the central rainfall $\left(P_{a+}\right)$, in which case the corresponding 

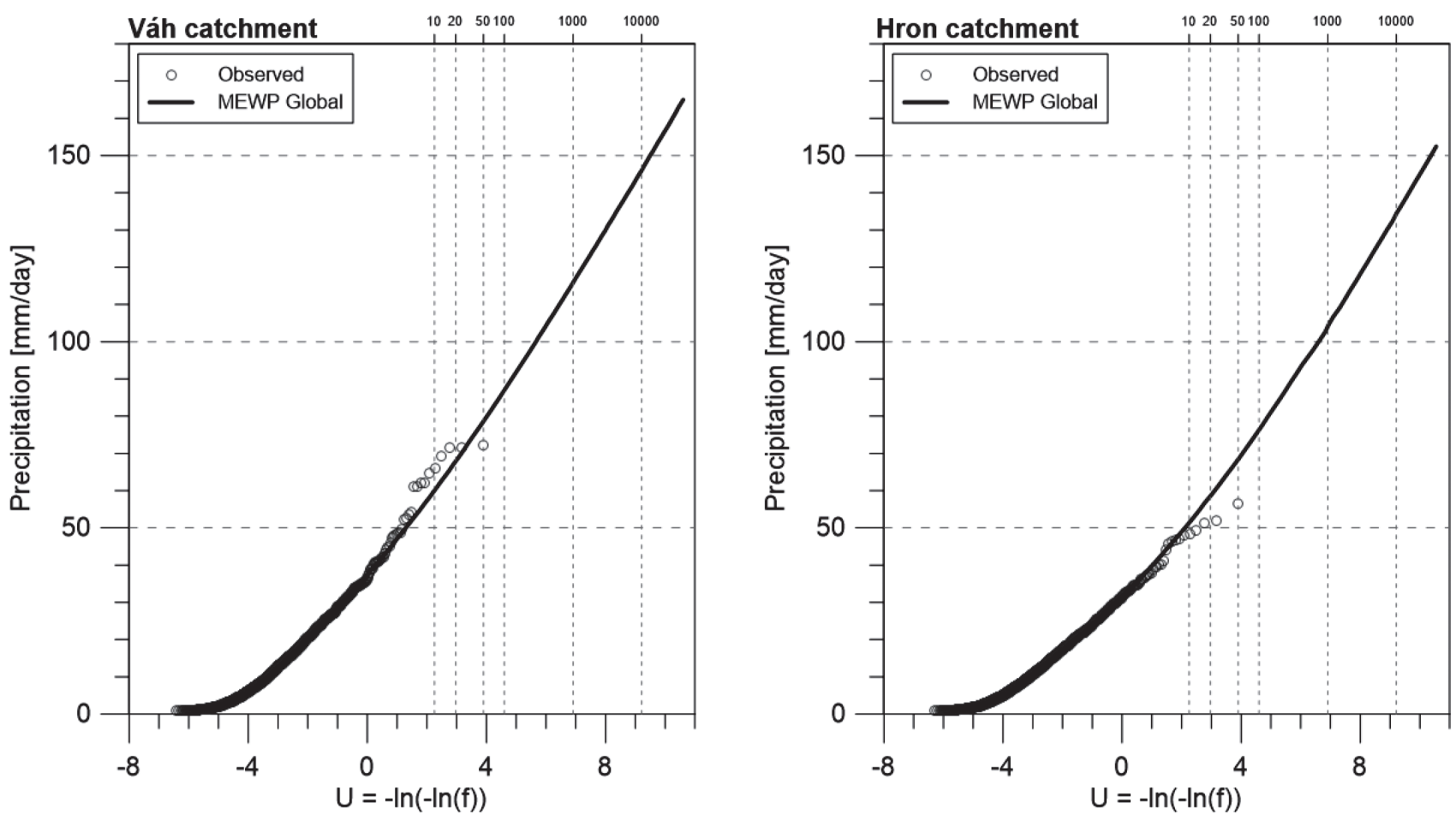

Fig. 9 Global CDFs of the MEWP probabilistic model of the central rainfall for the Váh (left image) and Hron catchments (right image).

mean weighted values of $R_{a+}$ are consistently higher in all four classes than those calculated for $P_{a-}$ (see Table 3). Identical results were obtained for the Hron catchment, with the same distribution of weights in the individual classes for both $P_{a-}$ and $P_{a^{+}}$.

A separate probabilistic model that accounted for the dependence between the centred rainfall event and the precipitation preceding this event was used. An autocorrelation between the central rainfall and the preceding ones showed that only the precipitation occurring
2 days before the rainfall event is statistically significant. The model computes correction factors for four different classes of three-day centred rainfall events and uses them to estimate the probabilities of the occurrence of a particular event that belongs to class $i$, and falls after an antecedent precipitation $P_{a n t}$. The complete scheme of the probabilistic rainfall model and a detailed description of its individual parts are thoroughly described in (Paquet et al., 2013).

Tab. 3 Empirical probabilities estimated for 4 different classes of central rainfall $(P)$ and used to estimate the ratios of the antecedent rainfall $\left(R_{d}\right)$ to the central rainfall. All the values in the table were estimated for the Váh catchment. The last row represents the mean weighted values of $R_{a}$.

Preceding

Following

\begin{tabular}{ccccccccc}
$R_{a}$ & Class 1 & Class 2 & Class 3 & Class 4 & Class 1 & Class 2 & Class 3 & Class 4 \\
& $P_{c} \in(1,6)$ & $P_{c} \in(6,14)$ & $P_{c} \in(14,23)$ & $P_{c} \in(23, \infty)$ & $P_{c} \in(1,8)$ & $P_{c} \in(8,17)$ & $P_{c} \in(17,29)$ & $P_{c} \in(29, \infty)$ \\
\hline 0.0 & 0.35 & 0.33 & 0.33 & 0.31 & 0.31 & 0.29 & 0.25 & 0.24 \\
0.1 & 0.15 & 0.13 & 0.14 & 0.19 & 0.15 & 0.16 & 0.22 & 0.23 \\
0.2 & 0.09 & 0.11 & 0.15 & 0.15 & 0.10 & 0.11 & 0.11 & 0.15 \\
0.3 & 0.08 & 0.09 & 0.08 & 0.09 & 0.08 & 0.09 & 0.09 & 0.10 \\
0.4 & 0.07 & 0.08 & 0.08 & 0.09 & 0.09 & 0.09 & 0.09 & 0.08 \\
0.5 & 0.06 & 0.06 & 0.05 & 0.07 & 0.07 & 0.07 & 0.06 & 0.06 \\
0.6 & 0.04 & 0.06 & 0.05 & 0.02 & 0.06 & 0.06 & 0.04 & 0.05 \\
0.7 & 0.06 & 0.06 & 0.04 & 0.04 & 0.05 & 0.05 & 0.06 & 0.02 \\
0.8 & 0.05 & 0.03 & 0.04 & 0.03 & 0.04 & 0.04 & 0.04 & 0.03 \\
0.9 & 0.07 & 0.05 & 0.04 & 0.02 & 0.06 & 0.04 & 0.05 & 0.03 \\
& & & & Weighted values of $R_{a}$ & & 0.28 & 0.28 & 0.27
\end{tabular}




\subsection{SCHADEX simulations and the estimation of design floods}

The SCHADEX simulations were run in a daily time step during the period between 1.11.1982 and 31.12.2010 (the first hydrological year was used as a warm-up period and thus omitted due to the uncertainties in the values of the model's state variables). Almost 30 years of observations ensured that a sufficient amount of various hydrological situations occurred in the catchments, including those responsible for a number of large flood events. The stochastic simulations were run in concordance with the simulation steps shown in Fig. 3. In both catchments approximately 72 three-day centred rainfall events were selected for every year of the simulation. For each event the peak flow induced by as much as $\sim 1000$ different synthetic rainfall events was calculated, which constituted $\sim 2$ million flows in each catchment throughout the whole simulation period. The quality of the SCHADEX simulation was visually assessed by comparing the theoretical CDFs of the mean daily discharges with the observed discharges associated with the centred rainfall events (Fig. 10). The results indicate a very good fit between the simulated SCHADEX distribution and the observed values, especially in the case of the Hron catchment. In the case of the Váh catchment it seems that the method might slightly overestimate discharges corresponding to the return periods of 10 or more years. However, since the empirical return periods of the observed values were only estimated from a very limited number of observations, they are associated with a relatively high degree of uncertainty. Table 4 also lists the values of the peak flows estimated for selected return periods for both of the catchments.

\section{DISCUSSION}

A better sense of the reliability of the extreme flood estimates might be achieved by putting the resulting SCHADEX CDFs into a context with some of the historical floods observed prior to the time

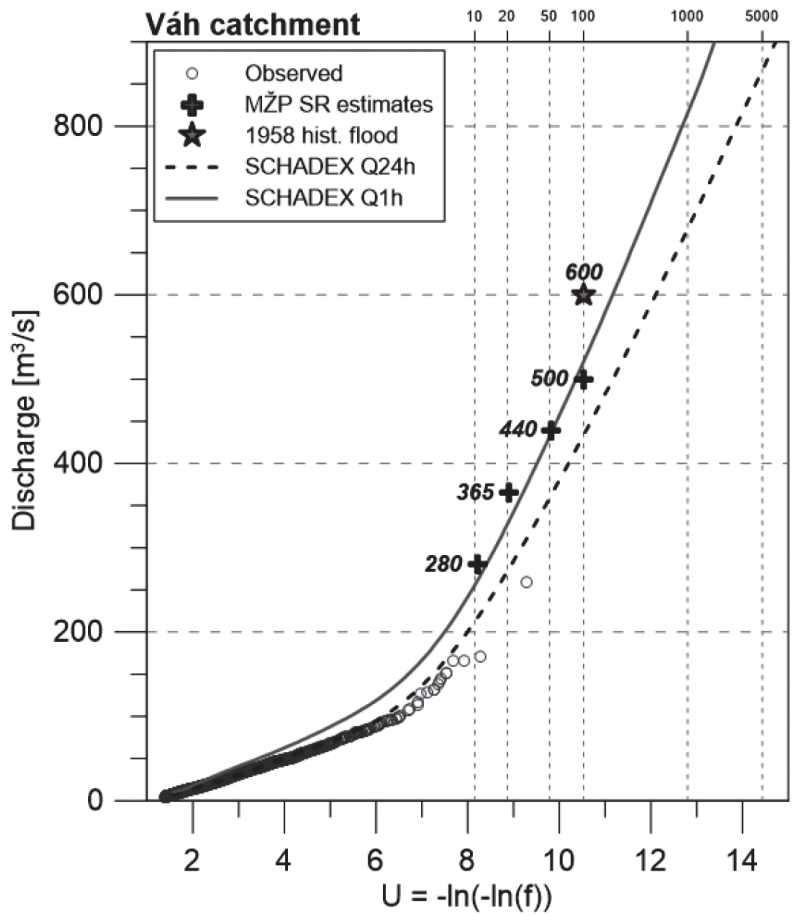

Tab. 4 SCHADEX peak flow estimates for selected return periods.

\begin{tabular}{ccc}
\hline \multirow{2}{*}{ Return period } & \multicolumn{2}{c}{ SCHADEX peak flows $\left[\mathrm{m}^{3} / \mathrm{s}\right]$} \\
\cline { 2 - 3 } & Váh & Hron \\
\hline 10 & 254 & 232 \\
20 & 330 & 273 \\
50 & 430 & 338 \\
100 & 517 & 400 \\
1000 & 818 & 637 \\
5000 & 1042 & 839 \\
\hline
\end{tabular}

period used in the analysis. The oldest information about the occurrence of floods comes from various historical documents and dates back to the $17^{\text {th }}$ (Váh) and $18^{\text {th }}$ (Hron) century. Despite the fact that their chronicle and impact on the inhabitants and their properties is well described, the estimates of their peak discharges and corresponding return periods is problematic and, in many cases, impossible. One of the first well-documented floods on the River Váh at Liptovský Mikuláš occurred in July 1958 with a peak discharge of $\sim 600 \mathrm{~m}^{3} / \mathrm{s}$ and an estimated return period of approximately 100 years (Bitara, 1998). In the case of the River Hron at Banská Bystrica, a catastrophic flood occurred in 1974 with an estimated peak discharge of $\sim 560 \mathrm{~m}^{3} / \mathrm{s}$ and the character of a 1000-year flood (Munkáči et al., 1998). When plotted together with the resulting SCHADEX CDFs (Fig. 10), it is possible to observe that in the case of the Váh catchment, the SCHADEX estimate for the 100-year flood is lower and, in the case of the Hron catchment and the corresponding 1000-year flood, it is higher. This might also be considered as a good sign, since the model does not systematically underestimate or overestimate design flows. However, when taking into account the uncertainties linked with the reconstruction of historical floods and the estimation of their return periods, one

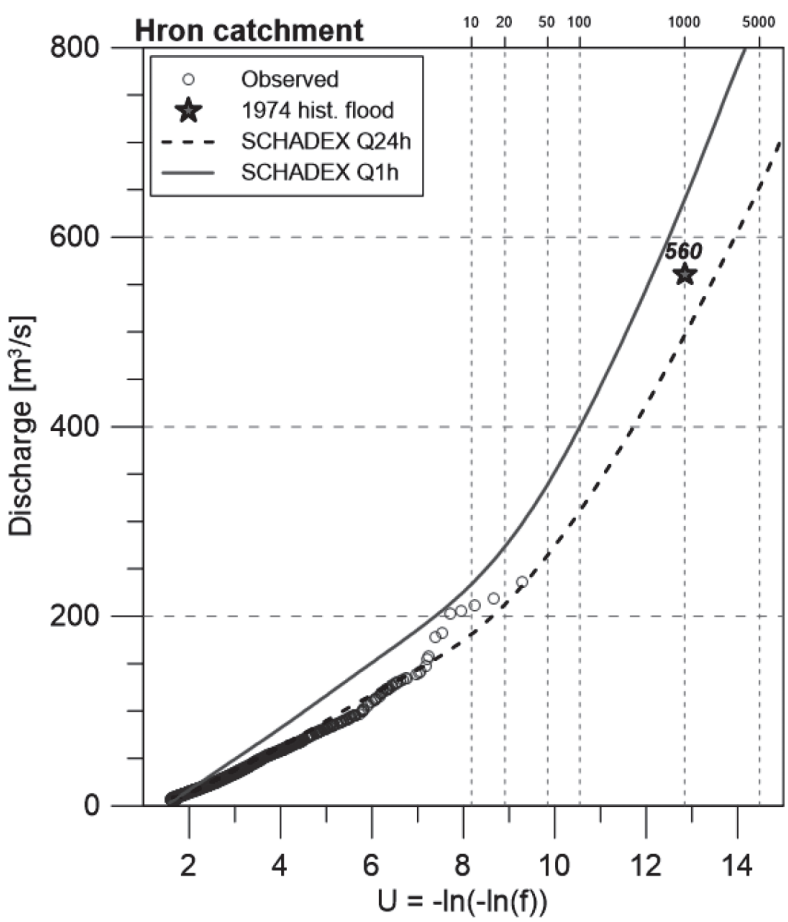

Fig. $10 C D F s$ of peak (Q1h) and mean daily $(Q 24 h)$ discharges estimated using the SCHADEX simulations. The graphs also show observed mean daily flows associated with centred rainfall events (empty circles) and historical floods with estimated return periods (stars). Left image - Váh catchment, right image - Hron catchment. 
might conclude that the SCHADEX method is capable of estimating peak flows of large return periods.

In the case of the Váh catchment, the results of the SCHADEX method were also compared to the extreme quantiles of peak flows, which were estimated using a statistical FFA by fitting a probabilistic distribution to a long series of annual maximum peak flows (MŽP SR, 2011). The peak flow estimates for return periods of $10,20,50$ and 100 years were plotted together with the SCHADEX CDFs in Fig. 10. The results are very coherent for return periods between 10 and 100 years.

\section{CONCLUSION}

The results of this study indicate that the design peak flows estimated by the SCHADEX method could be considered reliable. One of the biggest advantages of the method is that it enables the construction of a continuous CDF of peak flows, using input data in a much coarser time step (days in this case). Another advantage highlighted by Lawrence et al. (2014) is the capacity to generate a large range of possible rainfall magnitudes and catchment conditions, which can produce a $\mathrm{N}$-year discharge without the required assumption that a $\mathrm{N}$-year precipitation event produces a flood with the same return period. This is especially important for catchments with large contribution from snowmelt or base flow, where this assumption may lead to significant errors. When compared to the continuous simulation ap- proaches, the method is much more computationally efficient, which improves its usability in ensemble predictions or uncertainty evaluation studies. On the other hand, the method is relatively complex and thus not very suitable for a quick FFA. The user of the method must have sufficient experience in order to interpret the results and make the required adjustments (Lawrence et al., 2014). The method is also relatively demanding on the data, which is especially true when constructing the weather pattern classification (although this has only to be set once for a given area). Since the method requires both daily and hourly discharges (to estimate the peak-to-volume ratio), it is not straightforward to apply on ungauged or poorly documented catchments.

In spite of their drawbacks, the semi-continuous approaches such as the SCHADEX method are considered as one of those, eligible to estimate design discharges with very high return periods, which would be reliable enough to be used in the reevaluation or design of important water structures.

\section{Acknowledgement}

The authors gratefully acknowledge the VEGA grant agency for the support of grant No. 1/0891/17, the Slovak Research and Development Agency under the contract No. APVV-15-0497, as well as the COST Action ES0901 and its STSM programme. 


\section{REFERENCES}

Adams, B. J. - Howard, C. D. D. (1986) Design Storm Pathology, Canadian Water Resources Journal, 11, 3, pp. 49-55. DOI: 10.4296/cwrj1103049

Ailliot, P. - Allard, D. - Monbet, V. - Naveau, P. (2015) Stochastic weather generators: an overview of weather type models, Journal de la Société Française de Statistique, 156, 1, pp. 101-113.

ASCE (1996) Hydrology Handbook, New York, USA: American Society of Civil Engineers, 824 p. DOI: 10.1061/9780784401385 ISBN: 0-7844-0138-1

Asquith, W. H. - Bumgarner, J. R. - Fahlquist, L. S. (2003) A triangular model of dimensionless runoff producing rainfall hyetographs in Texas, Journal of the American Water Resources Association, 39, 4, pp. 911-921. DOI: 10.1111/j.1752-1688.2003.tb04415.x

Ball, J. - Babister, M. - Nathan, R. - Weeks, W. - Weinmann, E. Retallick, M. - Testoni, I. (eds.) (2016) Australian Rainfall and Runoff: A Guide to Flood Estimation, Commonwealth of Australia (Geoscience Australia) ISBN: 978-1-925297-07-2

Bezak, N. - Brilly, M. - Šraj, M. (2014) Comparison between the peaks-over-threshold method and the annual maximum method for flood frequency analysis, Hydrological Sciences Journal, 59, 5, pp. 959-977. DOI: 10.1080/02626667.2013.831174

Bitara, E. (1998) História povodni v povodi Váhu (History of floods in the Váh basin), Povodne a protipovodňová ochrana, Banská Štiavnica, Slovakia, pp. 16-20.

Blanchet, J. - Touati, J. - Lawrence, D. - Garavaglia, F. - Paquet, E. (2015) Evaluation of a compound distribution based on weather pattern subsampling for extreme rainfall in Norway, Natural Hazards Earth System Sciences, 15, 12, pp. 2653-2667. DOI: 10.5194/nhess-15-2653-2015

Blazkova, S. - Beven, K. (2004) Flood frequency estimation by continuous simulation of subcatchment rainfalls and discharges with the aim of improving dam safety assessment in a large basin in the Czech Republic, Journal of Hydrology, 292, 1-4, pp. 153172. DOI: $10.1016 / \mathrm{j} . j h y d r o l .2003 .12 .025$

Blöschl, G. - Sivapalan, M. - Wageener, T. - Viglioe, A. - Savenije, H. (eds.) (2013) Runoff Prediction in Ungauged Basins: Synthesis across Processes, Places and Scales, Cambridge University Press, 484 p. ISBN: 978-1-107-02818-0

Bobée, B. - Cavadias, G. - Ashkar, F. - Bernier, J. - Rasmussen, P. (1993) Towards a systematic approach to comparing distributions used in flood frequency analysis, Journal of Hydrology, 142, 1-4, pp. 121-136. DOI: 10.1016/0022-1694(93)90008-W

Boughton, W. - Droop, O. (2003) Continuous simulation for design flood estimation - a review, Environmental Modelling and Software, 18, 4, pp. 309-318. DOI: 10.1016/S1364-8152(03)00004-5

Boughton, W.C. - Hill, P.I. (1997) Report No. 97/8: A Design Flood Estimation Procedure Using Data Generation and a Daily Water Balance Model, Australia: Cooperative Research Centre for Catchment Hydrology, 48 p. ISBN: 1876006242
Bourqui, M. - Mathevet, T. - Gailhard, J. - Hendrickx, F. (2011) Hydrological validation of statistical downscaling methods applied to climate model projections, Hydro-climatology: Variability and Change, IAHS Publ. 344, Melbourne, Australia, 27 June -8 July, pp. 32-38. Available at: http://iahs.info/uploads/ dms/16758.09-32-38-344-33-JH02-abstract144-Bourqui-et-ACOR.pdf (Accessed: May 22, 2017)

Bras, R. L. - Gaboury, D. R. - Grossman, D. S. - Vicens, G. J. (1985) Spatially varying rainfall and floodrisk analysis, Journal of Hydraulic Engineering, 111, 5, pp. 754-773. DOI: 10.1061/ (ASCE)0733-9429

Brigode, P. - Bernardara, P. - Paquet, E. - Gailhard, J. - Garavaglia, F. - Merz, R. - Mićović, Z. - Lawrence, D. - Ribstein, P. (2014) Sensitivity analysis of SCHADEX extreme flood estimations to observed hydrometeorological variability, Water Resources Research, 50, 1, pp. 353-370. DOI: 10.1002/2013WR013687

Brigode, P. - Bernardara, P. - Paquet, E. - Gailhard, J. - Ribstein, P. - Merz, R. (2011) Complete application of the SCHADEX method on an Austrian catchment: extreme flood estimation on the Kamp river, EGU General Assembly 2011, Vienna, Austria, April 3-8. Available at: http://meetingorganizer.copernicus.org/ EGU2011/EGU2011-6771-1.pdf (Accessed: May 19, 2017)

Brigode, P. - Mićović, Z. - Bernardara, P. - Paquet, E. - Gailhard, J. - Garavaglia, F. - Garçon, R. - Ribstein, P. (2015) Méthodes probabilistes et déterministes d'estimation des débits extrêmes: comparaison de résultats sur deux bassins versants de Colombie-Britannique (Canada) (Probabilistic and deterministic extreme flood estimation methods: Estimation comparison on two British Columbia catchments (Canada)), La Houille Blanche, 3, pp. 72-78. DOI: 10.1051/1hb/20150036 (in French)

Brigode, P. - Paquet, E. - Bernardara, P. - Gailhard, J. - Garavaglia, F. - Ribstein, P. - Bourgin, F. - Perrin, C. - Andréassian, V. (2015) Dependence of model-based extreme flood estimation on the calibration period: the case study of the Kamp River (Austria), Hydrological Sciences Journal, 60, 7-8, pp. 1-14. DOI: 10.1080/02626667.2015.1006632

Cameron, D.S. - Beven, K.J. - Tawn, J. - Blazkova, S. - Naden, P. (1999) Flood frequency estimation by continuous simulation for a gauged upland catchment (with uncertainty), Journal of Hydrology, 219, 3-4, pp. 169-187. DOI: 10.1016/S0022-1694(99)00057-8

Camici, S. - Tarpanelli, A. - Brocca, L. - Melone, F. - Moramarco, T. (2011) Design soil moisture estimation by comparing continuous and storm-based rainfall-runoff modeling, Water Resources Research, 47, 5, 18 p. DOI: 10.1029/2010WR009298

Coutagne, A. (1954) Quelques considérations sur le pouvoir évaporant de l'atmosphère, le déficit d'écoulement effectif et le déficit d'écoulement maximum (Some considerations on the evaporating capacity of the atmosphere, the effective deficit of flow and the maximum deficit of flow), La Houille Blanche, 3, pp. 360-374. DOI: $10.1051 / \mathrm{hb} / 1954036$ (in French) 
Cunnane, C. (1973) A particular comparison of annual maxima and partial duration series methods of flood frequency prediction, Journal of Hydrology, 18, 3-4, pp. 257-271. DOI: 10.1016/00221694(73)90051-6

Cunnane, C. (1989) Report No. 33: Statistical distribution for flood frequency analysis, Geneva, Switzerland: Secretariat of the World Meteorological Organization, 73 p. DOI: $10.1080 / 00221689009499053$

Di Baldassarre, G. - Montanari, A. (2009) Uncertainty in river discharge observations: a quantitative analysis, Hydrology and Earth System Sciences, 13, 6, pp. 913-921. DOI: 10.5194/hess13-913-2009

Duan, Q. - Sorooshian, S. - Gupta, V. (1992) Effective and Efficient Global Optimization for Conceptual Rainfall-Runoff Models, Water Resources Research, 28, 4, pp. 1015-1031. DOI: 10.1029/91WR02985

DVWK (1999) Deutscher Verband für Wasserwirtschaft und Kulturbau, 1999. Hochwasserabflüsse - I. Einsatz von NiederschlagAbflussmodellen zur Ermittlung von Hochwasserabflüssen (Floods - On the use of rainfall runoff models for flood estimation), Bonn, Germany: DVWK-Schriften. (in German)

Eagleson, P.S. (1972) Dynamics of flood frequency, Water Resources Research, 8, 4, pp. 878-898. DOI: 10.1029/WR008i004p00878

FEH (1999) Flood Estimation Handbook, Wallingford, UK: Centre for Ecology and Hydrology.

Flores-Montoya, I. - Sordo-Ward, Á. - Mediero, L. - Garrote, L. (2016) Fully stochastic distributed methodology for multivariate flood frequency analysis, Water, 8, 6, p. 20. DOI: 10.3390/ w8060225

Gaál, L. - Kyselý, J. - Szolgay, J. (2008) Region-of-influence approach to a frequency analysis of heavy precipitation in Slovakia, Hydrology and Earth System Sciences Discussions, 12, 3, pp. 825-839. DOI: 10.5194/hess-12-825-2008

Gaál, L. - Szolgay, J. - Bacigál, T. - Kohnová, S. - Hlavčová, K. Výleta, R. - Parajka, J. - Bloschl, G. (2016) Similarity of empirical copulas of flood peak-volume relationships: a regional case study of North-West Austria, Contributions to Geophysics and Geodesy, 46, 3, pp. 155-178. DOI: 10.1515/congeo-2016-0011

Gamage, S. H. P. W. - Hewa, G. A. - Beecham, S. (2015) Modelling hydrological losses for varying rainfall and moisture conditions in South Australian catchments, Journal of Hydrology: Regional Studies, 4, pp. 1-21. DOI: 10.1016/j.ejrh.2015.04.005

Garavaglia, F. - Gailhard, J. - Paquet, E. - Lang, M. - Garçon, R. Bernardara, P. (2010) Introducing a rainfall compound distribution model based on weather patterns sub-sampling, Hydrology and Earth System Sciences, 14, 6, pp. 951-964. DOI: 10.5194/ hess-14-951-2010

Garavaglia, F. - Lang, M. - Paquet, E. - Gailhard, J. - Garçon, R. - Renard, B. (2011) Reliability and robustness of rainfall compound distribution model based on weather pattern sub-sampling, Hydrology and Earth System Sciences, 15, 2, pp. 519-532. DOI: $10.5194 /$ hess-15-519-2011
Garavaglia, F. - Le Lay, M. - Gottardi, F. - Garçon, R. - Gailhard, J. - Paquet, E. - Mathevet, T. (2017) Impact of model structure on flow simulation and hydrological realism: from lumped to semi-distributed approach, Hydrology and Earth System Sciences Discussions. DOI: 10.5194/hess-2017-82

Garavaglia, F. - Seyve, E. - Gottardi, F. - Le Lay, M. - Gailhard, J. - Garçon, R. (2014) Definition and sensitivity of the conceptual MORDOR rainfall-runoff model parameters using different multi-criteria calibration strategies, AGU Fall Meeting 2014, San Francisco, US, December 15-19. Available at: http://adsabs.harvard. edu/abs/2014AGUFM.H23K1024G (Accessed: May 22, 2017)

Garçon, R. (1996) Prévision opérationnelle des apports de la Durance à Serre-Ponçon à l'aide du modèle MORDOR. Bilan de l'année 1994-1995 (Operational forecast of the Durance's contribution to Serre-Ponçon using the MORDOR model. Review of the year 1994-1995), La Houille Blanche, 5, pp. 71-76. DOI: 10.1051/lhb/1996056 (in French)

Garçon, R. (1999) Modèle global pluie-débit pour la prévision et la prédétermination des crues (Overall rain-flow model for flood forecasting and pre-determination), La Houille Blanche, 7-8, pp. 88-95. DOI: 10.1051/lhb/1999088 (in French)

Grimaldi, S. - Serinaldi, F. (2006) Asymmetric copula in multivariate flood frequency analysis, Advances in Water Resources, 29, 8, pp. 1155-1167. DOI: 10.1016/j.advwatres.2005.09.005

Gupta, H. V. - Kling, H. - Yilmaz, K. K. - Martinez, G. F. (2009) Decomposition of the mean squared error and NSE performance criteria: Implications for improving hydrological modelling, Journal of Hydrology, 377, 1, pp. 80-91. DOI: 10.1016/j.jhydrol.2009.08.003

Hlavčová, K. - Kohnová, S. - Kubes, R. - Szolgay, J. - Zvolenský, M. (2005) An empirical method for estimating future flood risks for flood warnings, Hydrology and Earth System Sciences, 9, 4, pp. 431-448. DOI: 10.5194/hess-9-431-2005

Klemeš, V. (1993) Probability of extreme hydrometeorological events - a different approach, Extreme Hydrological Events: Precipitation, Floods and Droughts, IAHS Publ. no. 213, Yokohama, Japan, July 20-23, pp. 167-176.

Kohnová, S. - Gaál, L. - Bacigál, T. - Szolgay, J. - Hlavčová, K. - Valent, P. - Parajka, J. - Gunter, B. (2016) Process-based selection of copula types for flood peak-volume relationships in Northwest Austria: a case study, Contributions to Geophysics and Geodesy, 46, 4, pp. 245-268. DOI: 10.1515/congeo-2016-0015

Kohnová, S. - Solín, L. - Szolgay, J. (2003) Regionálna analýza maximálnych pretokov (Regional analysis of maximum flows), Životné prostredie, 37, 6, p. 8. (in Slovak)

Kohnová, S. - Szolgay, J. - Solín, L. - Hlavčová, K. (2006) Regional methods for prediction in ungauged basins, Ostrava: KEY Publishing, 113 p. ISBN: 80-87071-02-6

Lamb, R. (2005) Rainfall-runoff Modelling for Flood Frequency Estimation, In: Anderson, M. G. (ed.) Encyclopedia of Hydrological Sciences, Chichester, UK: John Wiley and Sons, pp. 1923-1953. ISBN: 0-471-49103-9 
Lang, M. - Pobanz, K. - Renard, B. - Renouf, E. - Sauquet, E. (2010) Extrapolation of rating curves by hydraulic modelling, with application to flood frequency analysis, Hydrological Sciences Journal, 55, 6, pp. 883-898. DOI: 10.1080/02626667.2010.504186

Lawrence, D. - Paquet, E. - Gailhard, J. - Fleig, A.K. (2014) Stochastic semi-continuous simulation for extreme flood estimation in catchments with combined rainfall-snowmelt flood regimes, Natural Hazards and Earth System Sciences, 14, 5, pp. 12831298. DOI: $10.5194 /$ nhess-14-1283-2014

Li, J. - Thyer, M. - Lambert, M. - Kuczera, G. - Metcalfe, A. (2014) An efficient causative event-based approach for deriving the annual flood frequency distribution, Journal of Hydrology, 510, pp. 412-423. DOI: 10.1016/j.jhydrol.2013.12.035

Li, J. - Thyer, M. - Lambert, M. - Kuzera, G. - Metcalfe, A. (2016) Incorporating seasonality into event-based joint probability methods for predicting flood frequency: A hybrid causative event approach, Journal of Hydrology, 533, pp. 40-52. DOI: 10.1016/j. jhydrol.2015.11.038

Loukas, A. - Quick, M. C. - Russell, S.O. (1996) A physically based stochastic-deterministic procedure for the estimation of flood frequency, Water Resources Management, 10, 6, pp. 415-437. DOI: 10.1007/BF00422548

Malekinezhad, H. - Nachtnebel, H. P. - Klik, A. (2011) Regionalization Approach for Extreme Flood Analysis Using L-moments, Journal of Agricultural Science and Technology, 13, pp. 11831196.

Mathevet, T. - Garavaglia, F. - Garçon, R. - Gailhard, J. - Paquet, E. (2009) Operational hydrological ensemble forecasts in France. Recent development of the French Hydropower Company (EDF), taking into account rainfall and hydrological model uncertainties, EGU General Assembly 2009, Vienna, Austria, April 19-24. DOI: 10.1029/2003WR002540 Available at: http://meetingorganizer.copernicus.org/EGU2009/EGU2009-10248.pdf (Accessed: May 22, 2017)

Munkáči, J. - Rigo, F. (1998) História povodni a protipovodñovej ochrany územnej pôsobnosti OZ Povodie Hrona (History of floods and flood control within territorrial scope of the Povodie Hrona Enterprises), Povodie a protipovodňová ochrana, Banská Štiavnica, Slovakia, pp. 21-28. (in Slovak)

MžP SR (2011) Predbežné hodnotenie povodňového rizika v čiastkovom povodi Váhu (Preliminary flood risk assessment in the Váh sub-basin), Ministerstvo Životného prostredia Slovenskej Republiky, 204 p. (in Slovak)

Nash, J. E. - Sutcliffe, J.V. (1970) River flow forecasting through conceptual models part I - A discussion of principles, Journal of Hydrology, 10, 3, pp. 282-290. DOI: 10.1016/00221694(70)90255-6

Newton, D. - Walton, R. (2000) Continuous Simulation for Design Flood Estimation in the Moore River Catchment, Western Australia, Hydro 2000: Interactive Hydrology, Institution of Engineers, Australia, pp. 475-480. ISBN: 0957824114 Available at: http://search.informit.com.au/documentSummary;d$\mathrm{n}=295514219578938 ;$;res=IELENG (Accessed: June 16, 2017)
Nicolle, P. - Pushpalatha, R. - Perrin, C. - François, D. - Thiéry, D. - Mathevet, T. - Le Lay, M. - Besson, F. - Soubeyroux, J.M. - Viel, C. - Regimbeau, F. - Andréassian, V. - Maugis, P. - Augeard, B. - Morice, E. (2014) Benchmarking hydrological models for low-flow simulation and forecasting on French catchments, Hydrology and Earth System Sciences, 18, 8, pp. 2829 2857. DOI: $10.5194 /$ hess-18-2829-2014

Papaioannou, G. - Kohnová, S. - Bacigál, T. - Szolgay, J. Hlavčová, K. - Loukas, A. (2016) Joint modelling of flood peaks and volumes: A copula application for the Danube River, Journal of Hydrology and Hydromechanics, 64, 4, pp. 382-392. DOI: 10.1515/johh-2016-0049

Paquet, E. - Garavaglia, F. - Garçon, R. - Gailhard, J. (2013) The SCHADEX method: A semi-continuous rainfall-runoff simulation for extreme flood estimation, Journal of Hydrology, 495, pp. 23 37. DOI: $10.1016 /$ j.jhydrol.2013.04.045

Paquet, E. - Lawrence, D. (2013) Extreme flood estimation by the SCHADEX method in a snow-driven catchment: application to Atnasjø (Norway), EGU General Assembly 2013, Vienna, Austria, April 7-12, Available at: http://meetingorganizer.copernicus.org/ EGU2013/EGU2013-8155.pdf (Accessed: May 19, 2017)

Rahman, A. - Haque, M.M. - Haddad, K. - Rahman, A.S. - Kuczera, G. - Weinmann, E. (2014) Assessment of the impacts of rating curve uncertainty on at-site flood frequency analysis : a case study for New South Wales, Australia, Hydrology and Water Resources Symposium 2014, Engineers Australia, Perth, Australia, February 14-27, pp. 962-969. Available at: http://researchdirect.westernsydney.edu.au/islandora/object/uws:27979 (Accessed: June 13, 2017)

Rahman, A. - Weinmann, P.E. - Hoang, T.M.T. - Laurenson, E.M. (2002) Monte Carlo simulation of flood frequency curves from rainfall, Journal of Hydrology, 256, 3-4, pp. 196-210. DOI: 10.1016/S0022-1694(01)00533-9

Rao, A. R. - Hamed, K. H. (2000) Flood frequency analysis, Boca Raton, USA: CRC Press, 350 p. ISBN: 9780849300837

Rogger, M. - Kohl, B. - Pirkl, H. - Viglione, A. - Komma, J. - Kirnbauer, R. - Merz, R. - Blöschl, G. (2012) Runoff models and flood frequency statistics for design flood estimation in Austria - Do they tell a consistent story?, Journal of Hydrology, 456-457, pp. 30-43. DOI: 10.1016/j.jhydrol.2012.05.068

Saghafian, B. - Golian, S. - Ghasemi, A. (2014) Flood frequency analysis based on simulated peak discharges, Natural Hazards, 71, 1, pp. 403-417. DOI: 10.1007/s11069-013-0925-2

Schlosser, T. - Nemec, N. - Borš, M. (2017) Tram track layout options in the area of Danube riverbank - Pribinova - Karadžičova in Bratislava, International Journal of Advanced Information and Technology, 6, 5, pp. 11-16. DOI: 10.15693/ijaist/2017.v6i5.11-16

Sun, Y. - Stein, M. L. (2016) A stochastic space-time model for intermittent precipitation occurrences, The Annals of Applied Statistics, 9, 4, pp. 2110-2132. DOI: 10.1214/15-AOAS875

Szolgay, J. - Gaál, L. - Bacigál, T. - Kohnová, S. - Hlavčová, K. Výleta, R. - Blöschl, G. (2016a) A regional look at the selection of a process-oriented model for flood peak/volume relationship, Proc. IAHS, 373, pp. 61-69. DOI: 10.5194/piahs-373-61-2016 
Szolgay, J. - Gaál, L. - Bacigál, T. - Kohnová, S. - Hlavčová, K. - Výleta, R. - Parajka, J. - Blöschl, G. (2016b) A regional comparative analysis of empirical and theoretical flood peak-volume relationships, Journal of Hydrology and Hydromechanics, 64, 4, pp. 367-381. DOI: 10.1515/johh-2016-0042

Szolgay, J. - Gaál, L. - Kohnová, S. - Hlavčová, K. - Výleta, R. Bacigál, T. - Blöschl, G. (2015) A process-based analysis of the suitability of copula types for peak-volume flood relationships, Proc. IAHS, 370, pp. 183-188. DOI: 10.5194/piahs-370-183-2015

Turc, L. (1954) Calcul Du Bilan De L'eau: Evaluation en Fonction des Precipitations et des Temperatures (Calculation of the Water Balance: Evaluation in function of precipitation and Temperatures), IAHS Rome Symposium, Rome, pp. 188-202. (in French)
Valent, P. - Výleta, R. (2015) Flood Frequency Analysis Using Continuous Simulation of Catchment Runoff, EGU General Assembly 2015, Vienna, Austria, April 12-17. Available at: http:// meetingorganizer.copernicus.org/EGU2015/EGU2015-321.pdf (Accessed: May 19, 2017)

Viglione, A. - Merz, R. - Blöschl, G. (2009) On the role of the runoff coefficient in the mapping of rainfall to flood return periods, Hydrological Earth System Sciences, 13, pp. 577-593. DOI: 10.5194/hess-13-577-2009

Zalachori, I. - Ramos, M.-H. - Garçon, R. - Mathevet, T. - Gailhard, J. (2012) Statistical processing of forecasts for hydrological ensemble prediction: a comparative study of different bias correction strategies, Advances in Science and Research, 8, 1, pp. 135-141. DOI: 10.5194/asr-8-135-2012 